\title{
PROBLEM-BASED LEARNING APPROACH ENHANCES THE PROBLEM SOLVING SKILLS IN CHEMISTRY OF HIGH SCHOOL STUDENTS
}

\author{
Joseph E. Valdez ${ }^{1}$ D, Melfei E. Bungihan ${ }^{* 2}$ (D) \\ ${ }^{1}$ College of Arts and Sciences, Nueva Vizcaya State University, Bayombong, Nueva Vizcaya (Philippines) \\ ${ }^{2}$ College of Teacher Education, Quirino State University, Diffun, Quirino (Philippines) \\ valdezjosephe@gmail.com, ${ }^{*}$ Correspondingauthor:fei_jan14@yahoo.com
}

Received December 2018

Accepted March 2019

\section{Abstract}

The study aimed to investigate the effectiveness of problem-based learning (PBL) approach in enhancing the problem solving skills in Chemistry of Grade 9 students in a public high school in the Philippines. The level of problem solving skills of the students in the non-PBL and PBL group before and after their exposure to non-PBL and PBL approaches was determined respectively. The comparison of their levels before and after the intervention was done to determine the effectiveness of the non-PBL and PBL approaches. Then comparison of the effectiveness of non-PBL and PBL approach was assessed. Using the descriptive-comparative and pretest-posttest experimental design in processing the data from 96 students, the following revelations were obtained: (1) the level of problem solving skills before and after their exposure to non-PBL approach is generally very low; (2) the level of problem solving skills was initially very low but was comparatively increased to low after exposure to PBL; (3) there was a significant difference in the level of problem solving skills of the students in the PBL group; (4) between these two approaches in this study, the PBL approach of teaching the chemistry concepts to Grade 9 students was proven more effective than the non-PBL approach.

Keywords - Problem-based learning, Problem solving skill, Pedagogy, Chemistry education

\section{To cite this article:}

Valdez, J., \& Bungihan, M. (2019). Problem-based learning approach enhances the problem solving skills in chemistry of high school students. Journal of Technology and Science Education, 9(3), 282-294. https://doi.org/10.3926/jotse.631

\section{Introduction}

It has always been the goal of every educational system to develop an individual who has the ability to think and process the knowledge acquired from the process of teaching and learning. These ideas and knowledge learned must be applied efficiently in the society. For the past decades, the status of Philippine Educational system has faced several challenges. It has undergone several reforms to be more appropriate to the present demands of the nation and the world in general, by reflecting the current vision of the content, classroom management, methods of teaching and support necessary to provide quality science education to students (Hofstein, 2005). 
One of the areas of concern in education is the method used in the teaching-learning process. During the learning process in class, teachers should recognize the way students think in order to help them construct their understanding and for them to create rich and meaningful interactions in the classroom. This will help the teacher ensure that transmission of knowledge will certainly take place (Mamlok-Naama, Hofstein \& Taitelbaum, 2012). Teacher's use of methods or strategies must also be dynamic to answer the needs of varied learners. This was supported by Minstrell and Stimpson (2000) and Mamlok-Naama et al. (2012), when they claimed that teachers should change their teaching strategies and adopt new strategies to make the teaching and learning process better.

Science teachers at present are facing great challenges in teaching chemistry as a subject. They have an indispensable responsibility of ensuring that students achieve the learning competencies desired for each specific topic in the subject. As students face challenges in mastering these competencies expected of them, teachers too are expected to face challenges in teaching. If teachers do not understand their learners' needs, then their instructional approaches will be a hit or a miss (Davis, 2006). Strategies must then be carefully chosen to fit the needs, interest, motivation and characteristics of the learners. A good teacher's approach to teaching and learning contributes more likely to higher quality learning outcomes. Therefore, it is important that teachers should carefully select the appropriate tools and strategies in delivering their lessons. These should fit the type of learners they have and it should improve and enhance the teaching-learning process (Lynch, Kuipers, Pyke \& Szesze, 2001; Schroeder, Linderman \& Choo, 2007). In addition, Zimmerman (2002) emphasizes that the strategy, tool or approach should teach students to become responsible learners and will make them realize that learning is an activity for themselves in a proactive way rather than a covert event despite their differences in learning styles.

After several encounters with pedagogies of teaching, an approach that would possibly provide solution on the ehancement of students' performance in the subject was identified. It is hypothesized that problem-based learning approach in learning will give positive results in the pursuit of elevating the performance of the students. With problem-based learning, it is believed that problem solving skills of the students will be enhanced. These skills will not only be applicable to science subjects but also in other subject areas and most importantly, in real life. They will also acquire skills that will help them in their interaction with the dynamic community or the society in general where they dwell. Problem solving is a strategy in "posing significant, contextualized, real world situations and providing sources, guidance and instruction to learners as they develop content knowledge and problem-solving skills" (Killen, 2007). It can be used as a part of a lesson, a theme of several lessons or as a structure of a substantial part of the curriculum - also known as problem-based learning or PBL. PISA or Program for International Student Assessment defines problem-solving as an individual's capability to participate in intellectual processing to comprehend and resolve problem situations where a method of solution is not directly apparent. It embraces the readiness to participate with such situations in order to achieve one's potential as a productive and reflective citizen (Macdonald, 2014).

Problem-based learning (PBL) in its most highly developed form is an approach to curriculum design and implementation rather than teaching strategy or method. This approach to teaching and learning was first applied and utilized in the field of medicine. When it was proven effective to medical students, several attempts were made to apply it in another field like teaching (Bransford, 2015). A PBL curriculum is designed around a comprehensive, real and complex problems that provide learners with opportunities to acquire the knowledge, understanding and skills that are defined by the curriculum outcomes. In its deepest sense, the problem is the curriculum which is the stimulus for each aspect of student's independent learning. The use of problem solving is based on the premise that sustained exposure with appropriate set of problems will help learners to acquire a substantial knowledge base, deepen their understanding of important concepts and principles, and develop skills (problem-solving skills and interpersonal skills) that are relevant to their future careers (Killen, 2007).

Chemistry learners must be good problem solvers. Problem solving is a dynamic, confusing process which is often annoying among students but the process can be rewarding. Students must learn to explore 
problems and understand that committing errors is as significant as knowing the correct answers or solutions. During the process, students must be perceptive so that they will realize if they are going farther or closer to the solution of the problem (Society Committee on Education, 2012). It is a necessary mandate of any educational system to enhance and develop the problem solving skills of students in order for them to be globally competitive. These skills of students can be enhanced if they are exposed to problem based learning approach wherein they encounter real life problems that require them to identify the problem, gather data for the problem, provide plausible solutions and finally decide on which of those solutions will effectively solve the problem (Dolmans, De Grave, Wolfhagen \& Van Der Vleuten, 2005).

While PBL has been proven effective in studies mentioned, its application in many high schools in the Philippines has not been as popular as traditional lecture with problem-solving activities. The problem-based learning matrix introduced as an enhancement or introduced strategy to the usual set-up of the public high school might develop further the problem solving skills of students. Thus, the purpose of the study was to determine the effectiveness of problem-based learning using a developed problembased learning matrix in enhancing the level of problem solving skills of Grade 9 students in a public high school in Philippines.

\section{Methodology}

\subsection{Model of Research}

The study utilized the descriptive-comparative research and pretest-posttest experimental designs. The descriptive part of the research involved the profiling of the student and determining their levels of problem solving skills. The comparative part involved the comparison of their levels during the pre- and post-test. The experimental part of the study involved the students' performance in chemistry after exposure to problem based-learning approach. Qualitative and quantitative approaches were utilized in determining the level of problem solving skills of students. Quantitative analysis was used to determine any difference between the pretest and posttest means of the experimental and the control groups.

\subsection{Implementation}

The study was conducted to four randomly selected classes of Grade 9 Integrated Science students of a public high school in the Philippines under the Revised Basic Education Curriculum for the school year 2015 - 2016. There were two classes for the non-PBL group. These consist of 50 students with 24 males and 26 females. These sections are heterogeneous and handled by another teacher. The PBL group also has two classes which consist of a total of 46 students, 14 males and 32 females. Students had their classes 240 minutes a week (4 sessions per week) and 60 minutes per session.

The research tools used were the (1) Problem-Based Learning Matrix which contained the desired learning competencies for the different learning topics, learning activities and assessment that were delivered and administered to the students during the duration of the research study. This learning plan/matrix was validated by experts (2) Problem-Based Learning Teacher's Guide which consisted of semi-detailed lesson plans in every lesson in each module. This served as a guide for the teacher to deliver the lesson to the learners with PBL approach successfully, (3) PBL Learning Material which was a learner's module developed by the researchers. It comprised four modules covering the four major topics of Grade 9 units for chemistry. Each module covers several lessons that expose students to thought-provoking problems and require students to determine their goals/objectives, provide plausible solutions and decide critically on the best solution to solve the problem and attain their identified objectives, (4) Problem Solving Skill Test (PSST) was an open-ended test for assessing the level of problem solving skills of the learners. Students were asked to solve a set of 10 problems under sufficient amount of time. An adapted rubric from NCRESST was used in assessing the level of problem solving skills of students (Patrick, Cragnolini, Smith, Worsfold \& Webb, 2016). The items in the problem solving test were also validated by experts. The rubric used the $0-4$ levels. The table below shows the equivalence of the levels. 


\begin{tabular}{|c|c|}
\hline Descriptions & Range of Levels \\
\hline Very low & $0-0.49$ \\
\hline Low & $0.50-1.49$ \\
\hline Average & $1.50-2.49$ \\
\hline High & $2.50-3.49$ \\
\hline Very high & $3.50-4.00$ \\
\hline
\end{tabular}

Table 1. Level of Problem Solving Skills

After the research and control groups have been selected, a pre-test for problem solving skill was administered to the PBL and non-PBL group. The results of the test were gathered and analyzed to determine the initial students' level of problem solving skills. Students in the PBL group were taught using the problem-based learning approach while the students in the non-PBL group were taught using the traditional learning approach as prescribed by the K-12 learning material (Learning Modules/Learning Guides). In the PBL based learning has the following main parts. First is the mini-lecture. At this initial stage, the researcher provided a short lecture regarding the topic. This served as a way to actively engage the students to the lesson. The introduction of the Problem Scenario followed immediately. The students, working as a group of 5 to 6 members, were given a problem scenario which was related to the topic at hand. Each member of the groups was given a copy of the problem. They were given sufficient time to discuss, organize their thought and solve the problem. Moreover, all of them were allowed to use all the available resources provided inside the learning environment in order to propose a plausible solution and supported by their logical reasons. The PBL method ended with the abstraction part. After stimulating a brain storming activity among the groups, their ideas were presented to the other groups. The researcher encouraged the students to accept new knowledge, correct the previous hypothesis if deemed necessary. The various groups presented their answers and were rated according to the rubric. The research took 40 class hours (10 weeks) in total.

Post-tests with 10 open-ended problem scenarios were administered to the students of PBL and non-PBL group after all the identified topics in Chemistry for Grade 9 were taught using the identified teaching and learning approaches. The results of the post-tests were the basis for identification of the levels of problem solving skills of students after their exposure to the two identified teaching approaches.

\subsection{Preparation, Implementation and Evaluation of the Problem Solving Skill Test (PSST)}

At the beginning a 15 open ended questions were prepared by the researcher in accordance to the desired learning competencies of grade 9 students under the Revised Basic Education Curriculum of the K to 12 Program of the Department of Education. The general subject matters include: a) Electronic Structure of the Atom, b) Chemical Bonding c) Carbon Compounds and d) The Mole Concept. The prepared material was assessed by three experts in the field of chemistry - a professor in a reputable university and two chemistry teachers. After the assessment of the material and based on the recommendations of the experts the open ended questions were reduced to 10 .

\begin{tabular}{|c|l|}
\hline Problem Scenario Number & \multicolumn{1}{c|}{ Topic to be Assessed } \\
\hline 1 & Electronic Structure of the Atom \\
\hline 2 & Mole Concept: \\
\hline 3 & Mole Concept \\
\hline 4 & Chemical bonding \\
\hline 5 & Organic Compounds \\
\hline 6 & Electronic Structure of the Atom \\
\hline 7 & Organic Compounds \\
\hline 8 & Mole Concept \\
\hline 9 & Chemical Bonding \\
\hline 10 & Electronic Structure of the Atom \\
\hline
\end{tabular}

Table 2. The topics included in the problem scenarios used in the problem-solving task 


\subsection{Data Collection and Assessment}

SPSS version 16 was used in the treatment of data. For the profile of the respondents, both the descriptive and quantitative statistics were used (frequency and percent). The significant difference of the level of problem solving skills in their pre-test and post-test performances was determined using t-test for dependent samples. To determine the significant difference of the level of problem solving skills of students exposed to PBL and non-PBL approach, T-test for independent samples was used.

Normalized average gain and effect sizes were used to determine the effectiveness of learning approaches implemented in this study. The effect sizes of the applied methods were interpreted based on Glass' delta calculations of t-test values. The Glass' delta values for effect size was processed using the Effect Size Calculator for T-test of Social Science Statistics (https://www.socscistatistics.com/effectsize/default3.aspx). Generally, the approaches effect sizes can be interpreted as low $(\mathrm{d}<0.2)$, medium $(0.20<\mathrm{d} \leq 0.80)$ and high $(\mathrm{d}>0.80)$. Effective approaches have effect sizes that fall within medium and high. The percent normalized average gain, Gain(\%) was calculated using Hake’s Gain Formula:

Gain $(\%)=\underline{\% \text { postscore }-\% \text { prescore }} \times 100$

100- \% prescore

where: Gain $(\%)$ is the percent gain scores of the students, \%postscore is the percentage of posttest score and \%prescore is the percentage of the pretest scores.

The Gain (\%) was interpreted as low (20\% and below), moderate (21\% to $70 \%)$ and high $(71 \%$ and above). Effectiveness of intervention has a Gain $(\%)$ that falls within moderate and high (Hake, 1998; 2007).

\subsection{Results and Discussion}

According to Quadros, Da Silva, Silva, De Andrade, Aleme, Tristao et al. (2011), chemistry is considered as a core science subject that permeates several areas of knowledge. Moreover, this is one of the components of the science curriculum that promotes intellectual development of the students, through various activities for students to understand nature and its transformation. Thus, clear understanding of the concepts provides opportunities for students to understand the world from a 'chemical' point of view. Society Committee on Education (2012) also stipulates that chemistry learners must be good problem solvers. Therefore, it is necessary that students' skills in problem solving be enhanced during chemistry instruction (Goodwin, 2001).

\subsection{Non-Problem Based Learning Approach}

In the problem solving skill test, students were given 10 real-life situations to answer in their pre-test and post-test. The result of their pre-and-post-test is revealed in Table 3. The table shows the level of their responses in the pre-test and post-test of their problem solving skills test.

\begin{tabular}{|l|c|c|c|c|c|c|}
\hline \multicolumn{1}{|c|}{ Problems } & \multicolumn{2}{c|}{ Pre } & \multicolumn{2}{c|}{ Post } & \\
\cline { 2 - 3 } & Mean & SD & Description & Mean & SD & Description \\
\hline $\begin{array}{l}\text { Situation 1 } \\
\text { You are looking for a gold necklace as a gift to your } \\
\text { mother on her birthday. A vendor offers you to buy a } \\
\text { necklace which he claims to be pure gold. It looks like } \\
\text { gold and the mass is close to that of gold. He is } \\
\text { offering you to buy it at a lower rate compared to the } \\
\text { other stores. Should you buy it or not? }\end{array}$ & 0.52 & 0.18 & Low & 0.59 & 0.50 & Low \\
\hline
\end{tabular}




\begin{tabular}{|c|c|c|c|c|c|c|c|c|}
\hline \multirow{2}{*}{\multicolumn{3}{|c|}{ Problems }} & \multicolumn{2}{|c|}{ Pre } & \multirow[b]{2}{*}{ Description } & \multicolumn{2}{|c|}{ Post } & \multirow[b]{2}{*}{ Description } \\
\hline & & & Mean & SD & & Mean & SD & \\
\hline \multicolumn{3}{|c|}{$\begin{array}{l}\text { Situation } 2 \\
\text { Phencyclidine or "angel dust" is } \mathrm{C}_{17} \mathrm{H}_{25} \mathrm{~N} \text {. Your group } \\
\text { has been analyzing a sample suspected of being this } \\
\text { illicit drug and you found that the substance has a } \\
\text { percentage of } 84.74 \% \mathrm{C}, 10.42 \% \mathrm{H} \text { and } 5.61 \% \mathrm{~N} \text {. Do } \\
\text { these data match the theoretical data for phencyclidine? }\end{array}$} & 0.12 & 0.04 & Very Low & 0.33 & 0.30 & Very Low \\
\hline \multicolumn{3}{|c|}{$\begin{array}{l}\text { Situation } 3 \\
\text { A newspaper story describing the local celebration of } \\
\text { Mole Day on October } 23 \text { (selected for Avogadro's } \\
\text { number } 6.02 \times 10^{23} \text { ) attempted to give their readers a } \\
\text { sense of size of the number by stating that a mole of } \\
\text { M\&M would be equal to } 18 \text { tractor trailers full. } \\
\text { Assuming that M\&M occupies a volume of } 0.5 \mathrm{~cm}^{3} \text {, } \\
\text { and a tractor has a volume of } 30,000,000 \mathrm{~cm}^{3} \text {. Would } \\
18 \text { trailers be sufficient? }\end{array}$} & 0.17 & 0.11 & Very Low & 0.20 & 0.31 & Very Low \\
\hline \multicolumn{3}{|c|}{$\begin{array}{l}\text { Situation } 4 \\
\text { "You already know that when hydrogen and chlorine } \\
\text { combine, they form hydrogen chloride, HCl. Hydrogen } \\
\text { chloride is a gas at room temperature and it becomes a } \\
\text { liquid if it is cooled to }-85^{\circ} \mathrm{C} \text {. On the basis of this } \\
\text { evidence, do you think that hydrogen chloride is ionic } \\
\text { or covalent?" }\end{array}$} & 0.25 & 0.10 & Very Low & 0.21 & 0.20 & Very Low \\
\hline \multicolumn{3}{|c|}{$\begin{array}{l}\text { Situation } 5 \\
\text { "Vitamin } \mathrm{C} \text { is a covalent compound with a molecular } \\
\text { formula, } \mathrm{C}_{6} \mathrm{H}_{8} \mathrm{O}_{6} \text {. A potato chips sold in the canteen is } \\
\text { enriched with Vitamin C. Instead of directly taking the } \\
\text { vitamin } \mathrm{C} \text { supplement readily available in the drugstore, } \\
\text { your friend preferred to eat the potato chips. However, } \\
\text { your friend does not know how much of the potato } \\
\text { chips will she eats. If one ounce of potato chips } \\
\text { provides with } 30 \% \text { of the recommended daily value of } \\
\text { Vitamin } \mathrm{C} \text {, how many servings of potato chips will you } \\
\text { tell your friend to eat to get } 100 \% \text { of recommended } \\
\text { daily value of this vitamin?" }\end{array}$} & 0.39 & 0.12 & Very Low & 0.47 & 0.35 & Very Low \\
\hline \multicolumn{3}{|c|}{$\begin{array}{l}\text { Situation } \mathbf{6} \\
\text { Your chemistry teacher presents the table below to your } \\
\text { classmate. }\end{array}$} & \multirow{9}{*}{0.07} & \multirow{9}{*}{0.05} & \multirow{9}{*}{ Very Low } & \multirow{9}{*}{0.17} & \multirow{9}{*}{0.15} & \multirow{9}{*}{ Very Low } \\
\hline Element & Atomic Number & $\begin{array}{l}\text { Electronegativity } \\
(\mathrm{g} / \mathrm{mL})\end{array}$ & & & & & & \\
\hline Beryllium & 4 & 1.6 & & & & & & \\
\hline Boron & 5 & 2.0 & & & & & & \\
\hline Carbon & 6 & 2.6 & & & & & & \\
\hline Fluorine & 9 & 4.0 & & & & & & \\
\hline Lithium & 3 & 1.0 & & & & & & \\
\hline Oxygen & 8 & 3.4 & & & & & & \\
\hline \multicolumn{3}{|c|}{$\begin{array}{l}\text { You were instructed to help him make a general } \\
\text { statement for the trend in the electronegativity in terms } \\
\text { of atomic number. }\end{array}$} & & & & & & \\
\hline
\end{tabular}




\begin{tabular}{|c|c|c|c|c|c|c|}
\hline \multirow[b]{2}{*}{ Problems } & \multicolumn{2}{|c|}{ Pre } & \multirow[b]{2}{*}{ Description } & \multicolumn{2}{|c|}{ Post } & \multirow[b]{2}{*}{ Description } \\
\hline & Mean & SD & & Mean & SD & \\
\hline $\begin{array}{l}\text { Situation } 7 \\
\text { Your brother came home late one evening from a } \\
\text { birthday party. He was drunk, his face was flushed and } \\
\text { he was perspiring profusely. You know that he could be } \\
\text { quite irritable. This had already happened several times } \\
\text { in the past. As a member of the family and one who } \\
\text { knows about the psychological effects of alcohol, what } \\
\text { will you advise to your brother to lessen his drinking } \\
\text { habits? }\end{array}$ & 0.43 & 0.05 & Very Low & 0.75 & 0.08 & Low \\
\hline $\begin{array}{l}\text { Situation } 8 \\
\text { Your mother needs to buy her medicine in a drug store. } \\
\text { When she was there she came across two drugs } \\
\text { specified to have the same chemical formula and } \\
\text { approved by the Bureau of Food and Drugs. One drug } \\
\text { has a well-known brand name while the other was } \\
\text { manufactured by another company and sells at a lower } \\
\text { price. What will you advice to help your mother decide? }\end{array}$ & 0.31 & 0.05 & Very Low & 0.71 & 0.06 & Low \\
\hline $\begin{array}{l}\text { Situation } 9 \\
\text { Joe accidentally dropped some iron filings into a salt } \\
\text { solution. With no idea on how to separate the iron } \\
\text { filings from the mixture, he then asked you to suggest } \\
\text { ways that could help him separate the filings. }\end{array}$ & 0.01 & 0.01 & Very Low & 0.37 & 0.15 & Very Low \\
\hline $\begin{array}{l}\text { Situation } 10 \\
\text { "A miner in Runruno, Quezon, found a nugget that has } \\
\text { a gold color. He realized that it could be a precious gold } \\
\text { metal or pyrite, which is a compound of iron and sulfur } \\
\text { called fool's gold. The nugget has a mass of } 16.5 \mathrm{~g} \text { and } \\
\text { displaced } 3.3 \mathrm{~mL} \text { of water. From this information, can } \\
\text { you tell the miner that he found a real gold or not? } \\
\text { What will you tell him to solve his problem?" }\end{array}$ & 0.04 & 0.00 & Very Low & 0.19 & 0.17 & Very Low \\
\hline Overall & 0.23 & 0.17 & Very Low & 0.40 & 0.21 & Very Low \\
\hline
\end{tabular}

Note: $3.5-4.0$ = "very high", $2.5=3.49$ = "high", $1.5-2.49=$ "average", $0.50-1.49=$ "low", $0-0.49=$ "very low"

Table 3. The Level of Problem Solving skills of the Non-PBL Group in the Items of the Problem Solving Skill Test

Among the 10 problems presented during the pre-test, answers of the students in Situation 1 exhibited the highest mean of 0.52 (low). Moreover, answers of students in Situation 9 surfaced the lowest mean of 0.01 (very low).

Table 4 presents the level of problem solving skills before and after they were taught using the nonPBL approach of teaching chemistry concepts in Science 9.

\begin{tabular}{|c|c|c|c|c|}
\hline \multirow[b]{2}{*}{ Level } & \multicolumn{2}{|c|}{ Before } & \multicolumn{2}{|c|}{ After } \\
\hline & f & $\%$ & f & $\%$ \\
\hline Very High & 0 & 0 & 0 & 0 \\
\hline High & 0 & 0 & 0 & 0 \\
\hline Average & 0 & 0 & 0 & 0 \\
\hline Low & 4 & 8.00 & 14 & 28 \\
\hline Very Low & 46 & 92.00 & 36 & 72 \\
\hline Overall & \multicolumn{2}{|c|}{ mean $=0.23($ very low $), S D=0.13$} & \multicolumn{2}{|c|}{ mean $=0.40$ (very low), $\mathrm{SD}=0.16$} \\
\hline
\end{tabular}

Note: $3.5-4.0$ = "very high", $2.5=3.49$ = "high", 1.5 - $2.49=$ "average", $0.50-1.49=$ "low", $0-0.49=$ "very low"

Table 4. Level of Problem Solving Skills of the Non-PBL Group before and after Exposure to Non-PBL Approach 
It can be gleaned from the table that students of the non-PBL group have very low problem solving skills (mean $=0.23, \mathrm{SD}=0.13)$ before they were exposed to non-PBL approach of teaching. Most $(92 \%$ of the total 46 students) of the students have very low level of problem solving skills while few ( $8 \%)$ students have low level of problem solving skills.

After exposure to non-PBL approach in learning chemistry concepts, the number of student in the low level slightly increased $(28 \%)$ while the number of students in the very low level slightly decreased $(72 \%)$. However, the level of problem solving skills of non-PBL group still remained at low level with a mean of $0.40(\mathrm{SD}=0.16)$. This implies that the approach used in teaching did not have a remarkable effect in increasing the student's level of problem solving skills. In addition to this, there could be limited opportunities for students to develop and enhance this skill. A related study was conducted by Hasna (2004) and found out that the problem solving skills of the students were not fully enhanced by just using the traditional way of teaching and eventually suggested another approach - the PBL approach.

The level of problem solving skill of the Grade 9 students in the non-PBL group during their pre-test was compared to their level during the post-test. Using paired sample t-test analysis, the significant difference of their problem solving skills during their pre-and post-test is determined as shown in Table 5.

\begin{tabular}{|l|r|r|r|r|r|}
\hline & \multicolumn{1}{|c|}{ Mean } & \multicolumn{1}{c|}{ SD } & t-value & Df & \multicolumn{1}{c|}{ Sig } \\
\hline Pre-test & 0.23 & 0.13 & 4.381 & & 9 \\
\cline { 1 - 3 } Post-test & 0.40 & 0.16 & & $0.000^{*}$ \\
\hline
\end{tabular}

*significant at 0.05

Table 5. Paired Sample t-test Analysis (Pre-and-Post-tests) of the Problem Solving Skills of the Non-PBL Group

Table 5 shows that there is a significant difference in the pre-and-post-test levels of problem solving skills of the non-PBL students after their exposure to non-PBL approach of learning chemistry. The post-test mean level $(0.40)$ difference of 0.17 over the pre-test mean level $(0.23)$ indicates that the non-PBL approach of teaching chemistry concepts among the students in the non-PBL group significantly helped in enhancing their level of problem solving skills.

\subsection{Problem-Based Learning Approach}

During the pre-test and post-test of students' problem solving skills, they were given the same 10 situations/problems to answer as in the non-PBL group (Table 3). Their responses were evaluated and the result is presented in Table 6 .

.Table 6 shows that Grade 9 students under the PBL group generally exhibited very low level of problem solving skills during the pre-test of the problem solving skill test which surfaced a mean of 0.31 . Among the 10 situations given during the pre-test, responses of students showed highest level of problem solving skills in Situation 1 with a mean of 0.75 (low). The responses of the students in Situations 3 and 6 exhibit the lowest level with a mean of 0.04 (very low). The very low level of problem solving skills of students in the PBL group prior to their exposure to PBL approach suggests that their skills in problem solving are not yet enhanced. 


\begin{tabular}{|c|c|c|c|c|c|c|}
\hline \multirow[b]{2}{*}{ Problems } & \multicolumn{2}{|c|}{ Pre } & \multirow[b]{2}{*}{ Description } & \multicolumn{2}{|c|}{ Post } & \multirow[b]{2}{*}{ Description } \\
\hline & Mean & SD & & Mean & SD & \\
\hline Situation 1 & 0.75 & 0.26 & Low & 1.48 & 0.43 & Low \\
\hline Situation 2 & 0.14 & 0.08 & Very low & 1.21 & 0.43 & Low \\
\hline Situation 3 & 0.04 & 0.03 & Very low & 0.24 & 0.06 & Very low \\
\hline Situation 4 & 0.09 & 0.05 & Very low & 0.64 & 0.07 & Low \\
\hline Situation 5 & 0.25 & 0.09 & Very low & 0.52 & 0.04 & Low \\
\hline Situation 6 & 0.04 & 0.01 & Very low & 0.96 & 0.08 & Low \\
\hline Situation 7 & 0.71 & 0.10 & Low & 1.00 & 0.12 & Low \\
\hline Situation 8 & 0.62 & 0.13 & Low & 0.97 & 0.09 & Low \\
\hline Situation 9 & 0.39 & 0.08 & Very low & 0.77 & 0.39 & Low \\
\hline Situation 10 & 0.20 & 0.07 & Low & 0.10 & 0.02 & Very low \\
\hline Overall & 0.31 & $\mathrm{SD}=0.26$ & Very low & 0.73 & $\mathrm{SD}=0.41$ & Low \\
\hline
\end{tabular}

Note: $3.5-4.0=$ "very high", $2.5=3.49=$ "high", $1.5-2.49=$ "average", $0.50-1.49=$ "low", $0-0.49=$ "very low"

Table 6. The Level of Problem Solving Skills of the PBL Group in the Items of the Problem Solving Skill Test

The level of problem solving skills of students under the PBL group before and after they were taught using the PBL approach is presented in Table 7.

\begin{tabular}{|c|c|c|c|c|}
\hline \multirow[b]{2}{*}{ Levels } & \multicolumn{2}{|c|}{ Before } & \multicolumn{2}{|c|}{ After } \\
\hline & f & $\%$ & f & $\%$ \\
\hline Very High & 0 & 0 & 0 & 0.00 \\
\hline High & 0 & 0 & 0 & 0.00 \\
\hline Average & 0 & 0 & 0 & 0 \\
\hline Low & 11 & 23.9 & 35 & 76.1 \\
\hline Very Low & 35 & 76.1 & 11 & 23.9 \\
\hline Overall & \multicolumn{2}{|c|}{$\begin{array}{c}\text { mean }=0.32(\text { very low }) \\
\mathrm{SD}=0.21\end{array}$} & \multicolumn{2}{|c|}{$\begin{array}{c}\text { mean }=0.79(\text { low }) \\
\mathrm{SD}=0.31\end{array}$} \\
\hline
\end{tabular}

Note: $3.5-4.0=$ "very high", $2.5-3.49=$ "high", 1.5 - $2.49=$ "average", $0.50-1.49=$ "low", $0-0.49=$ "very low"

Table 7. Level of Problem Solving Skills of the PBL Group before and after Exposure to PBL Approach

As gleaned from Table 7, the level of problem solving skills of students under the PBL group before they were exposed to PBL approach of learning the concepts of chemistry was very low $(76.10 \%)$ and few $(23.90 \%)$ of the students showed low level of problem solving skills. Generally, the PBL group has very low level of problem solving skills with average mean level of 0.32 with $\mathrm{SD}=0.21$ during the pre-test. None among the students exhibited higher level of problem solving skills.

Moreover, the level of problem solving skills during the post-test after they were exposed to PBL approach of learning chemistry concepts was low as indicated by an average mean level of 0.79 with standard deviation of 0.31 . Specifically, most $(76.10 \%)$ of the students displayed low level of problem solving skills and few $(23.90 \%)$ of them showed very low level. It has to be noted that the number of students in the low level comparatively increased $(76.10 \%)$ after they were exposed to PBL. On the other hand, the higher number of students in the very low level comparatively decreased $(23.90 \%)$ during the post test. This implies that the intervention made provided a positive effect in developing and enhancing the problem solving skills of the students. These results agree with the findings of Dochy, Segers, den Bossche and Gijbels (2003) that students who were exposed to PBL have immediate and lasting problem solving skills. White (2001) also said that PBL not only improves the skills of the students but also makes students realize the connections of the concepts when they learn facts and skills as they actively work on the information rather than passively receive it. In addition, there are evidences that PBL effectively 
develops reasoning skills and problem solving skills and enhances self-directed learning (HmeloSilver,2004).

The significant difference of level of problem solving skills of students under the PBL group before and after they were taught was determined using paired sample T-test analysis. The results are shown in Table 8.

\begin{tabular}{|l|r|r|r|r|r|}
\hline \multicolumn{1}{|c|}{ Experimental design } & \multicolumn{1}{c|}{ Mean } & \multicolumn{1}{c|}{ SD } & t-value, q & df & \multicolumn{1}{c|}{ Sig } \\
\hline Pre-test & 0.32 & 0.21 & 11.021 & 45 & $0.000^{*}$ \\
\hline Post-test & 0.79 & 0.31 & & & \\
\hline
\end{tabular}

*significant at 0.05

Table 8. Paired Sample t-test Analysis (Pre-and-Post tests) of the Problem Solving Skills of the PBL Group

As gleaned from table, there is significant difference in the pre-and-post test results of level of problem solving skills of the PBL group of Grade 9 students. The post-test mean level (0.79) difference of 0.47 over the pre-test mean level (0.32) indicates that the PBL approach used in teaching the PBL group of Grade 9 students significantly helped in elevating their level of problem solving skills. This is supported by the results of the studies which clearly specified that PBL efficiently develops the problem solving skills and reasoning skills of students (Antepohl \& Herzig, 1999; Hmelo-Silver, Duncan \& Chin, 2007; Hmelo-Silver, 2004). Moreover, students in the PBL group may have developed their judgement skills in choosing the best solution for the identified problem. But it has to be noted that the mean level is still low and this might be affected by the type, characteristics and attitude towards problem situations of students present within the group (Mergendoller, Maxwell \& Bellisimo, 2006).

\subsection{Comparison of the PBL and Non-PBL Group}

Data analysis on the gain scores of students in the PBL and non-PBL group depending on their raw scores obtained from PSST is presented in Table 9.

\begin{tabular}{|l|r|r|r|r|r|r|r|r|}
\hline & \multicolumn{4}{|c|}{ PBL Group N=46 } & \multicolumn{3}{c|}{ Non-PBL Group N=50 } \\
\cline { 2 - 8 } & $\begin{array}{c}\text { Pre-test } \\
\text { Average }\end{array}$ & $\begin{array}{c}\text { Post-test } \\
\text { Average }\end{array}$ & Gain(\%)* & Description & $\begin{array}{c}\text { Pre-test } \\
\text { Average }\end{array}$ & $\begin{array}{c}\text { Post-test } \\
\text { Average }\end{array}$ & Gain(\%)* & Description \\
\hline $\begin{array}{l}\text { Problem } \\
\text { Solving Skill }\end{array}$ & 0.32 & 0.79 & 11 & low & 0.23 & 0.40 & 4 & low \\
\hline
\end{tabular}

$*$ low $=20 \%$ and below, moderate $=20 \%<\mathrm{g} £ 70 \%$, high $=$ greater than $70 \%($ Hake, 2007)

Table 9. Percent Gain of Problem Solving Skills of PBL and Non-PBL Group

The gain scores are derived from the average pre-test and post-test scores of students from the assessment tool. It should be noted that the students were grouped in heterogeneous classes. At the start (during pretest), the students grouped in the PBL have higher percentage belonging to the higher level of problem solving skills as shown in Table 4 than in the non-PBL group shown in Table 7. A significant number of students (52\%) in the PBL group upgraded to a higher level, as compared to only $20 \%$ in the non-PBL group. This higher percent gain by the PBL group may be justified by the fact that most of them have already a higher problem solving skill at the start compared to the non-PBL group. However, based on the results shown in Table 9, although there is an increase in the scores of the students, the learning gain for problem solving skill in the non-PBL group (4\%) and PBL group (11\%) are still both classified as "low" based on the description of Hake (2007). This may be attributed to the learning environment, to the characteristic and behavior of learners and their readiness and the length of implementation of the program (Albanese, 2000; Hmelo-Silver, 2004; Lim, 2013). Furthermore, class interruptions during the implementation and the teacher's proficiency in implementing the approach to the students may also be factors to the low problem solving skills of the students. 
Using the gain scores of students obtained from their raw scores in PSST, the significant difference in their initial level (during the pre-test) of problem solving skill from their final level (during the post-test) was determined using t-test for independent samples. The results are given in Table 10.

\begin{tabular}{|c|c|c|c|c|c|c|c|}
\hline Groups & $\mathbf{N}$ & Mean & SD & $\mathbf{T}$ & df & $\mathrm{p}$ & Description \\
\hline PBL & 46 & 11.15 & 6.86 & \multirow{2}{*}{2.52} & \multirow{2}{*}{94} & \multirow{2}{*}{$0.014^{*}$} & \multirow{2}{*}{ Significant } \\
\hline non-PBL & 50 & 4.18 & 29.18 & & & & \\
\hline
\end{tabular}

*significant at 0.05

Table 10. Comparison of the Gain Scores on the Level of Problem Solving Skill of PBL and Non-PBL Groups

According to the data presented, the level of problem solving skill of students in the PBL group is significantly different $(\mathrm{t}=2.52, \mathrm{p}<0.005)$ from the non-PBL group. The PBL mean (11.15) difference of 6.97 over the non-PBL (4.18) indicates that the level of problem solving skills under the PBL group is better than those in the non-PBL group. The high problem solving skill of the PBL group is attributed to the training they have during the teaching learning process. These students were generally exposed to real-world problems, and as they solve these problems, their thinking, judgment and decision making skills were enhanced.

To determine the effect of the PBL and non-PBL approaches applied to PBL and non-PBL group respectively on the problem solving skill of the students, their scores in the PSST were used as the measure. Data gathered from this assessment is presented in Table 11.

\begin{tabular}{|c|c|c|c|c|c|c|c|c|}
\hline \multicolumn{2}{|c|}{ Groups } & $\mathbf{N}$ & Mean & SD & $\mathrm{t}$ & df & $\operatorname{sig}$ & Glass'-delta \\
\hline \multirow{2}{*}{ PBL } & Pre-test & \multirow{2}{*}{46} & 0.32 & 0.21 & \multirow{2}{*}{11.02} & \multirow{2}{*}{45} & \multirow{2}{*}{$0.000 *$} & \multirow{2}{*}{$2.10^{* *}$} \\
\hline & Post-test & & 0.79 & 0.31 & & & & \\
\hline \multirow{2}{*}{ NPBL } & Pre-test & \multirow{2}{*}{50} & 0.23 & 0.13 & \multirow{2}{*}{4.38} & \multirow{2}{*}{49} & \multirow{2}{*}{$0.000^{*}$} & \multirow{2}{*}{$0.85^{* *}$} \\
\hline & Post-test & & 0.40 & 0.16 & & & & \\
\hline
\end{tabular}

*significant at $0.05 ; * *$ low $(\mathrm{d} \leq 0.20)$, medium $(0.20<\mathrm{d} \leq 0.80)$, high $(\mathrm{d}>0.80)$

Table 11. Pre- and Post-test Mean Values Obtained from Problem Solving Skill Test, t-test Results and Effect Size Scores as “Glass' - delta” from Each Group

It can be seen that the effect size of PBL approach applied to Grade 9 students under PBL group is higher than the effect size of non-PBL approach applied to non-PBL group. It is apparent that the effect of PBL applied to the students in the PBL group is at a high level $(\mathrm{d}=2.10)$. The effect size of non-PBL is also at a high level $(\mathrm{d}=0.85)$ (Irven \& Corlu, 2011). These results suggest that PBL approach appears to be more effective than the non-PBL approach in enhancing the problem solving skill of students in the PBL group.

\section{Conclusion}

With the findings of the study, it was proven that the problem-based learning approach used in the study has been effective in enhancing the problem solving skills of the students. Moreover, Problem-based based learning is more effective than non-problem based learning in enhancing the level of problem solving skills of students.

\section{Declaration of Conflicting Interests}

The authors declared no potential conflicts of interest with respect to the research, authorship, and/or publication of this article. 


\section{Funding}

The authors received no financial support for the research, authorship, and/or publication of this article.

\section{References}

Albanese, M. (2000). Problem-based Learning: Why curricula are likely to show little effect on knowledge and clinical skills? Medical Education, 4(3), 729-738. https://doi.org/10.1046/j.1365-2923.2000.00753.x

Antepohl, W., \& Herzig, S. (1999). Problem-based learning versus lecture-based learning in a course of basic pharmacology; A controlled, randomized study. Medical Education, 106-113.

https://doi.org/10.1046/j.1365-2923.1999.00289.x

Bransford, J.E. (2015). Curriculum and instruction: A 21st century skills implementation guide. Available at: www.21stcenturyskills.org

Davis, E.A. (2006). Challenges new science teachers face. Review of Educational Research, 76(4), 607-651. https://doi.org/10.3102/00346543076004607

Dochy, F., Segers, M., den Bossche, P.V., \& Gijbels, D. (2003). Effects of problem-based learning: A metaanalysis. Learning and Instruction, 13, 534-568. https://doi.org/10.1016/S0959-4752(02)00025-7

Dolmans, D., De Grave, W., Wolfhagen, I., \& Van Der Vleuten, C. (2005). problem-based learning: Future challenges for educational practice and research. Medical Education, 39, 732-741.

https://doi.org/10.1111/j.1365-2929.2005.02205.x

Goodwin, A. (2001). Teachers' continuing learning of Chemistry: Implications for pedagogy. Institute of Education, 3(3), 1-8.

Hake, R. (1998). Interactive-engagement versus traditional methods: A six-thousand student survey of mechanics test data for introductory Physics. American Journal of Physics, 1(2), 64-74.

https://doi.org/10.1119/1.18809

Hake, R. (2007). Six lessons from the Physics education reform. Latin American Journal for Physics Education, $1(1), 24-31$.

Hasna, A.M. (2008). Problem based learning in engineering design. European Society for Engineering Education, $1(1), 1-11$

Hmelo-Silver, C.E. (2004). Problem-based Learning: What and how do students learn? Educational Psychology Review, 13(6), 236-266. https://doi.org/10.1023/B:EDPR.0000034022.16470.f3

Hmelo-Silver, C.E., Duncan, R.G., \& Chin, C. A. (2007). Scaffolding and achievement in problem-based and inquiry learning: A response to to Kirschner, Sweller, and Clark. Educational Psychologist, 42(2), 99-107. https://doi.org/10.1080/00461520701263368

Hofstein, A. (2005). Chemistry teachers' professional development for the implementatin on new content and pedagogical standards. Chemical Education International, 6(1), 1-8.

Irven, F., \& Corlu, M. (2011). Contribution of video analysis of elevator experiments to Physics achievement. Eurasian Journal of Physics and Chemistry Education (Special Issue), 2-8.

Killen, R. (2007). Effective teaching strategies. Victoria, Australia: Social Science Press.

Lim, C. (2013). Building pre-service teacher's ICT in education competencies at Edith Cowan University (Australlia). In G.-J. Kim. Case studies on integrating ICT into teacher education curriculum in asia (1-10). Bangkok, Thailand: UNESCO Bangkok. 
Lynch, S., Kuipers, J., Pyke, C., \& Szesze, M. (2001). Examining the effects of a highly rated science curriculumun on diverse students: Results from a planning grant. Journal of Research in Science Teaching, 42, 921-946.

Macdonald, G. (2014). Teaching and assesing problem solving skills-PIS A Recommendations. Available at: http://www.oecd.org/pisa/kevfindings/pisa-2012-results-volume-v.html

Mamlok-Naaman, R., Hofstein, A., \& Taitelbaum, D. (2012). Enhancing the pedagogical content knowledge of teachers by using an evidence-based inquiry approach in the Chemistry laboratory. Mevlana International Journal of Education, 2(3), 62-68.

Mergendoller, J., Maxwell, N., \& Bellisimo, Y. (2006). The Effectiveness of problem-based instruction: A comparative study of instructional method and student characteristics. Interdisciplinary Journal of Problembased Learning, 1(2), 49-69. https://doi.org/10.7771/1541-5015.1026

Minstrell, J., \& Stimpson, V. (2000). A classroom environment for learning: Guiding students' reconstruction of understanding and reasoning. Innovations in learning: New environments for Education, 1(1), 175-202.

Patrick, C.G., Cragnolini, V., Smith, C., Worsfold, K., \& Webb, F. (2016). Griffith Institute for Higher Education. Problem solving skills toolkit. Available at: https://www.griffith.edu.au/ data/assets/pdf file/0008/290717/Problem-solving-skills.pdf

Quadros, A.L., Da Silva, D.C., Silva, F.C., De Andrade, F.P., Aleme, H.G., Tristao, J.C. et al. (2011). The knowledge of chemistry in secondary education: Difficulties from the teachers' viewpoint. Chemistry Education, 2(1), 232-239.

Schroeder, R.G., Linderman, K.W., \& Choo, A.S. (2007). Method and context perspectives on learning and knowledge creation in quality management. Journal of Operations, 25(4), 918-931.

https://doi.org/10.1016/j.jom.2006.08.002

Society Committee on Education (2012). ACS guidelines and recommendations for the teaching of high school Chemistry. Washington, DC: American Chemical Society.

White, H. (2001). Problem-based learning. Speaking of Teaching, 1(2), 1-8.

Zimmerman, B.J. (2002). Becoming a self-regulated learner: An overview. Theory into Practice, 41(2), 64-70. https://doi.org/10.1207/s15430421 tip4102_2

Published by OmniaScience (www.omniascience.com)

Journal of Technology and Science Education, 2019 (www.jotse.org)

(c) (i) (9)

Article's contents are provided on an Attribution-Non Commercial 4.0 Creative commons International License. Readers are allowed to copy, distribute and communicate article's contents, provided the author's and JOTSE journal's names are included. It must not be used for commercial purposes. To see the complete licence contents, please visit https://creativecommons.org/licenses/by-nc/4.0/. 